\title{
Working With Refugees in the U.S.: Trauma-Informed and Structurally Competent Social Work Approaches
}

\author{
Jason Ostrander \\ Alysse Melville \\ S. Megan Berthold
}

\begin{abstract}
Social workers, government, and non-governmental organizations in the United States have been inadequately prepared to address the impact of trauma faced by refugees fleeing persecution. Compounding their initial trauma experiences, refugees often undergo further traumatic migration experiences and challenges after resettlement that can have long-lasting effects on their health and mental health. Micro and macro social work practitioners must understand the impact of these experiences in order to promote policies, social work training, and clinical practice that further the health and well-being of refugees and society. Social workers are in a unique position to provide multi-dimensional, structurally competent care and advocacy for diverse refugee populations. The experiences of Cambodian refugees will be used to examine these issues. We will explore the benefits of an ecological perspective in guiding interventions that support refugees, and will apply the framework of structural competence to highlight multidimensional implications for social work with refugee populations.
\end{abstract}

Keywords: Refugees; trauma; ecological perspective; structural competence

Of the 21.3 million refugees worldwide, more than 3.3 million $(15.5 \%)$ have been resettled in the United States since 1975 (United Nations High Commissioner for Refugees, 2016). Refugees are individuals who were forcibly displaced from their home and across an international border due to conflict or persecution. A refugee is a person who,

owing to well-founded fear of being persecuted for reasons of race, religion, nationality, membership of a particular social group or political opinion, is outside the country of his nationality and is unable or, owing to such fear, is unwilling to avail himself of the protection of that country. (UN General Assembly, 1951, Article 1[A][2])

They flee seeking safety. Oppression, discrimination, war, and other traumatic experiences are common (UNHCR, 2016). As global crises continue, and the need for refugee resettlement grows, social workers must rise to address the unique needs of this population. The refugee experience does not simply begin upon entry in the host country, but instead is comprised of a "continuum of displacement, transition, and resettlement" (Catolico, 2013). Working with refugees requires an understanding of their pre-migration, migration, and post-migration trauma and other experiences (George, 2012).

\footnotetext{
Jason Ostrander, PhD, MSW is Assistant Professor, Department of Social Work, Sacred Heart University, Fairfield, CT 06825. Alysse Melville, MSW, LSW is a PhD student, School of Social Work, University of Connecticut, Hartford, CT 06103. S. Megan Berthold, PhD, LCSW is Associate Professor \& Director of Field Education, School of Social Work, University of Connecticut, Hartford, CT 06103. 


\section{Pre-Migration \& Transition}

Many refugees have been forced into migration and resettlement due to exposure to violence and/or other traumas in their home country, including political violence, discrimination, child abuse, war, human trafficking or other human rights violations. Refugees report high rates of torture, including witnessing torture of family members or others, physical beating, rape/sexual assault, and deprivation of food and water (Hooberman, Rosenfeld, Lhewa, Rasmussen, \& Keller, 2007). Estimated rates of torture exposure reported by refugees living in the United States range from 21\% (Steel et al., 2009) to $44 \%$ (Higson-Smith, 2015). However, these numbers may underreport the true rate, in part due to stigma and fear associated with disclosure experienced by survivors. Malnutrition is also a common pre-migration experience of refugee adults and children. A recent study of 982 refugee children aged 0 to 10 newly arrived in the United States found that $45 \%$ experienced at least one form of malnutrition (Dawson-Hahn, Pak-Gorstein, Hoopes, \& Matheson, 2016).

Unfortunately, with a few notable exceptions (Willard, Rabin, \& Lawless, 2014), refugee screening upon arrival in the United States often does not include assessment of exposure to torture and other traumas pre-migration. Only half of U.S. states reported providing any mental health screening to recently arrived refugees, and of those, less than half directly asked refugees about war trauma or torture exposure (Shannon et al., 2012). This was despite the fact that refugees experience high rates of trauma during the premigration and transition experience. Many communities do not offer culturally-appropriate and linguistically accessible services to treat trauma and torture in any or all of the refugee groups resettling in their area, a violation of refugee rights to adequate health care (United Nations Committee on Economic, Social and Cultural Rights, 2000).

Trauma in one's home country is often not the sole adversity experienced during the process of refugee migration. Poorer outcomes have been noted for refugees who are displaced into temporary or institutional accommodations, such as refugee camps, compared to those who are placed in permanent, private residences in the host country (Porter \& Haslam, 2005; Steel et al., 2009). Many refugee camps have documented patterns of abuse, excessive force, inhumane treatment, health risks (including communicable disease and lead exposure), and other human rights violations (Janmyr, 2014).

\section{Resettlement}

Issues that impact refugees upon resettlement include potential marginalization, socioeconomic disadvantage, acculturation difficulties, loss of cultural and social support, and cultural bereavement (Porter \& Haslam, 2005). These issues must be considered as part of the migration experience. Refugee families may resettle into temporary or unstable housing and face employment and financial stressors. In addition, studies of post-migration challenges that refugees in developed countries face have documented exposure to community violence (Berthold, 2000), limited social networks (Dharod, Xin, Morrison, Young, \& Nsonwu, 2013), difficulty finding formal childcare (Morantz, Rousseau, Banerji, Martin, \& Heymann, 2013), and food-related challenges (Dharod et al., 2013). 
Current federal support for refugees resettling in the United States covers health care, financial subsidies, case management services, English as a Second Language classes, and employment/job readiness services (Office of Refugee Resettlement, 2016). As noted above, refugees may be screened in the states in which they resettle; however, the screening content (namely whether it includes physical and/or mental health screening) is at the discretion of state policies, and often is merely an informal, conversational screening, if any (Shannon et al., 2012). Benefits offered to refugees are limited to an 8-month period, after which only provisionary support is offered to those who qualify.

As an acknowledgement of the high prevalence of torture experienced by refugees and asylum-seekers (and some other immigrants) in the United States, federal support is provided to agencies that deliver specialized services to torture survivors. The Torture Victims Relief Act (TVRA) of 1998 recognizes the need that many torture survivors have for rehabilitation, and outlines the authorization of U.S. funding to provide treatment and social and legal services for torture-exposed refugees, research, as well as training to support health care providers working with these refugees (TVRA, 2016). The Services for Survivors of Torture Program of the Office of Refugee Resettlement provides approximately $\$ 10.5$ million annually towards grants to agencies to provide traumainformed, holistic, and strengths-based services to torture survivors and their families to promote rehabilitation (ORR, 2016).

However, support for refugees varies significantly at the state level, with little consideration by federal agencies for the health needs of incoming refugees when deciding resettlement locations (Agrawal \& Venkatesh, 2016). Despite the efforts of the Torture Victims Relief Act, there are insufficient specialty clinics to serve all tortured refugees in need. U.S. social service systems often remain complex and difficult to navigate, and some torture survivors face eligibility restrictions for these programs, leading to difficulty accessing or paying for health care services (Ku \& Matani, 2001; National Consortium of Torture Treatment Programs, 2015).

This paper seeks to explore the experience of Cambodian refugees in the United States more than three decades' post-resettlement. This case study of a single refugee group will be used to better understand the ecological impact of the refugee experience, and to provide recommendations for practice, policy, and education for those working with and advocating for refugee populations.

\section{Cambodian Displacement \&Transition in Refugee Camps}

One of the largest genocides in the past century was perpetrated in Cambodia from 1975-1979 by the Khmer Rouge. Approximately 1.5 million Cambodians died as a result of starvation or murder (Kiernan, 2008). Those who survived recounted high rates of trauma and torture, including near-death starvation, death threats, forced labor, the murder of family members or friends, and witnessing beatings and killings (Marshall, Schell, Elliott, Berthold, \& Chun, 2005; Mollica, Brooks, Tor, Lopes-Cardozo, \& Silove, 2014; Mollica et al., 1993). Additionally, head trauma has been reported by those who survived the genocide, with prevalence rates documented as high as 18\% (Mollica et al., 1993). 
Following the end of the Pol Pot regime in 1975, over 500,000 fled Cambodia to be resettled in host countries (Tasker, 1993). During the time of transition, many Cambodians were settled temporarily in refugee or displaced persons camps. Some Cambodians spent many years in these Thai-Cambodian border camps, where reports of lack of food, water, shelter, and medical care were documented (Mollica et al., 1993). Those who survived the Khmer Rouge regime were more likely uneducated and unskilled laborers, and also more likely to be widowed women (Kula \& Paik, 2016). While high rates of poor self-reported health, PTSD, and depression have been documented in Cambodians in a Thai-Cambodian border camp (Mollica et al., 1993), a number of protective factors, such as positive work status and economic activity, involvement in religious practices, and involvement in caretaking activities have also been identified (Mollica, Cui, McInnes, \& Massagli, 2002). Such protective factors would be valuable to promote in current refugee and displaced persons camps and in countries of resettlement.

\section{Cambodian Resettlement}

Approximately 190,000 Cambodian refugees resettled in the United States following the end of the Pol Pot regime (National Cambodian American Health Initiative, 2007), with the highest numbers arriving between 1979 and 1986 (Kula \& Paik, 2016). Most had limited proficiency in English and were faced with restricted education and employment opportunities upon resettlement. Coupled with the impact of their traumatic experiences, these factors compromised the early efforts of Cambodian refugees at becoming selfsufficient. During initial resettlement, much of the support to the newly arriving Cambodians came in the form of time-limited cash assistance from the Office of Refugee Resettlement. Cambodian Mutual Assistance Associations (CMAAs), community-based organizations founded in the 1980s to support acculturation and resettlement, provided grass-roots community support. The CMAAs were staffed with Cambodians and provided support in a number of areas, including medical translation, advocacy, family supports, and navigating social services (NCAHI, 2007). In the 1990s, there were around 150 CMAAs nationwide; however, decreases in federal policies that impacted refugee and immigrant communities resulted in increased difficulties for resettled Cambodians as well as for the CMAAs, which have since dwindled to approximately seven today ( $\mathrm{Lu}, 2016$ ).

Once resettled in the United States, many Cambodians experienced high rates of poverty and community violence (Berthold, 2000; Kula \& Paik, 2016; Marshall et al., 2005). As noted above, Cambodians resettling from Thai-Cambodian border camps also had documented rates of poor self-reported health, depression, PTSD, various somatic complaints, physical pain, and functional limitations (Mollica et al., 1993). By 2014, the U.S. Census had documented over 326,000 Cambodian residents in the United States, of whom $51 \%$ were foreign-born (US Census Bureau, 2014). In recent years, documentation of health disparities in the Cambodian community have proliferated. More than two decades after resettling in the United States, Cambodians continue to experience high rates of past-year depression (51\%) and PTSD (62\%), much greater than the 7\% and 3\% rates for the same conditions found in the general U.S. population (Marshall et al., 2005). Comorbid PTSD and depression continued to be experienced by many Cambodians three decades after resettling in the United States (Berthold, Kong, Mollica, Kuoch, Scully, \& 
Franke, 2014). Additionally, Cambodian refugees have disproportionate rates of selfreported poor health, compared to both the general population and other Asian populations (Wong et al., 2011), with higher than average rates of diabetes and cardiovascular risk factors (Marshall, Schell, Wong, Berthold, Hambarsoomian, Elliott, \& Gregg, 2016).

The current poverty rate for Cambodians is around $17.5 \%$, a rate $2 \%$ higher than that of the general population and 5\% higher than composite Asian populations (US Census Bureau, 2014). A 2013 study of Cambodian refugee women documented persistent high rates of household food insecurity, even two decades after resettlement (Peterman, Wilde, Silka, Bermudez, \& Rogers, 2013). Those who resettled earlier (in the 1980s) reported greater persistent food insecurity than those who arrived later. Additionally, over one-third of Cambodians over 25 have less than a high school diploma (Kula \& Paik, 2016), highlighting ongoing economic and educational disparities impacting the Cambodian community.

Differential generational impacts have been observed between Cambodians who resettled in the United States as adults, as young adults, and as young children, as well among their U.S. born offspring. Cambodians in the United States have often found themselves trying to "straddle" different cultural systems, those that promote traditional Cambodian values and those shaped by mainstream Western values. Many younger Cambodians do not speak Khmer well or at all, and are unable to communicate effectively with those from older generations, some of whom have limited English proficiency, thus limiting the cultural "passing down" of knowledge and sharing of experiences. Despite these cultural challenges, Cambodians have exhibited great resilience in creating new strategies and environments to respond to intergenerational conflict (Lewis, 2010), such as the creation of programs to support intergenerational bonding through senior-youth engagement activities (Yoshida, Henkin, \& Lehrman, 2013).

Whole community models of intervention have been successfully used with Cambodian refugees to address health and mental health disparities within the community (Wagner, Berthold, Buckley, Kuoch, \& Scully, 2015). These interventions are relationshipdriven, culturally-centered, and address physical-psychosocial-spiritual needs and engage community health workers as supports to clinical care. Community health workers have served as a bridge between Western services and Cambodian refugees (Lu, 2016). Interventions that engage the community with a culturally-appropriate, strengths-based approach have included faith-based outreach by temples, churches, and other faith-based groups. These efforts combine health education outreach by faith communities, involvement of revered community elders, and transportation support. Such wholecommunity interventions have proved beneficial in increasing communication between Cambodian refugees and health care providers, medication compliance, and cultural competence in health care providers, and at the same time decreasing chronic disease symptoms (Grigg-Saito, Och, Liang, Toof, \& Silka, 2008; Grigg-Saito et al., 2010; Wagner et al., 2015). However, obtaining ongoing funding to sustain such community-driven interventions and securing buy-in from busy health care professionals may be a challenge to implementing whole community models for refugees. 


\section{Theoretical Lens}

Refugees and asylum-seekers continue to seek to enter or resettle in the United States as persecution persists and wars rage in countries such as Syria, Iraq, and Afghanistan. Ecological theory provides support for the importance of a multi-dimensional treatment approach by social workers serving refugees, and is a prominent and oft-cited theory in the social work literature (Rotabi, 2007). This framework serves as a holistic theoretical approach to help understand and organize information about refugees and their sociopolitical environments in the United States. Refugees and their families do not exist in isolation and are engaged in larger social systems, which intertwine with individuals and communities. Bronfenbrenner's (1979) ecological framework posits an interconnectedness between a person and his or her environment. In order to apply this framework to understand the experiences of refugees, we must conceptualize these refugees as embedded in an interactive multi-leveled system, which are separated into five nested subsystems consisting of the microsystem, mesosystem, exosystem, macrosystem, and chronosystem. Societal problems, such as poor health outcomes, family dynamics, community violence, unemployment, and language difficulties, fit well within this model (Hepworth, Rooney, Rooney, Strom-Gottfried, \& Larsen, 2010).

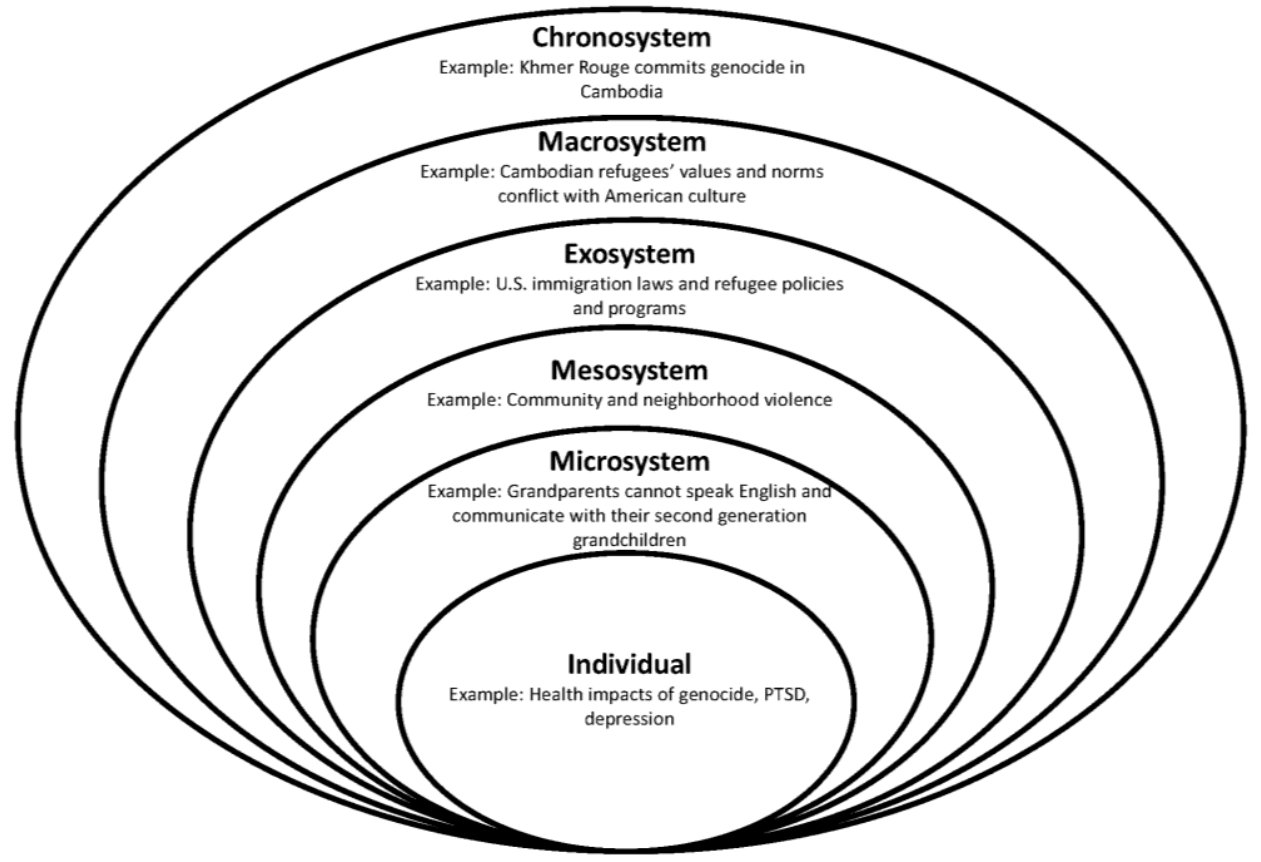

A structural competency approach is congruent with an ecological framework and can assist social workers to frame and organize the life experiences and multisystem forces, such as economic, political, and social determinants that impact refugees. Metzl and Hansen (2014) define structural competency "as the trained ability to discern how a host of issues defined clinically as symptoms, attitudes, or diseases...also represent decisions about such matters as health care and food delivery systems, zoning laws, urban and rural 
infrastructures" (p. 128). This approach has five intersecting skill sets: 1) recognizing how economic, physical, and socio-political structures shape clinical interactions (i.e., insurance companies dictating how long and what type of services they will cover); 2) developing clinical language to explain the impact of social environments on one's health (i.e., the effect racism has on cortisol levels); 3) understanding the importance of culture for different class and ethnic groups and recognizing how structural inequalities and barriers can manifest themselves as interpersonal communication and institutional practices; 4) understanding that structures, such as laws and policies, that shape health and illness are not immutable and can be altered through structural interventions (i.e., creation of an intervention program to address rural mental health needs); and 5) developing structural humility in order to hear and understand the nuances in individual clients stories (Metzl \& Hansen, 2014). Incorporating ecological theory and structural competency into practice will not only strengthen social workers' understanding of the unique and potentially traumatic experiences of resettling refugees, but also the contextual factors that impact them daily in their new communities (e.g., neighborhood violence, the lack of culturally appropriate services).

\section{Implications for Social Work}

It is incumbent upon social workers to understand the health statuses, psychosocial well-being, and challenges faced by refugee populations in the United States in order to promote appropriate policies, educate interdisciplinary health teams, and inform clinical social work practice. Trauma-informed social workers do not ask refugees, "What's wrong with you?" Instead, they ask "What happened to you?" (Substance Abuse and Mental Health Services Administration, 2014). Trauma-informed systems of care, framed by ecological theory, expand the focus of intervention from the therapeutic hour between a social work practitioner and refugee to encompass the broader agency and organizational systems as well as relevant structural factors in society.

\section{Practice Implications}

Implementing a structural competency approach within a trauma-informed system of care provides social work practitioners with the tools to look beyond microsystem interactions (e.g., social worker and client) and encourages them to look more holistically at structural inequalities and social determinants (i.e., racism and discrimination) that shape and constrain an individual's experiences (Metzl \& Hansen, 2014). This is reinforced by a human rights-based approach to clinical practice (Berthold, 2015). Social workers play a critical role in providing quality services to refugees in a variety of direct care positions, including as members of interdisciplinary teams. The NASW (2016) has recently supported such practice-based interventions through a recommendation in the Standards for Social Work Practice in Health Care Settings manual, which recommends that assessment processes are customized for a number of vulnerable populations, including refugees. Ways in which assessments may be adapted for refugees, however, are not explicitly outlined. When conducting assessments, social workers must ensure all facets of the refugee's life are evaluated, which cannot be limited to the present. Rather, social work professionals must understand the interconnectedness and depth of the refugee's life journeys which 
include past experiences of trauma in his or her home country, during migration, and when resettling in the new host country (George, 2012). Social workers must also be aware of the link between trauma exposure and health risks for refugee populations, and can provide psychoeducation to refugees as well as to providers in the different systems of care working with refugees. Social workers should work with cultural humility (Metzl \& Hansen, 2014) and determine if potential formal and informal natural supports such as immediate and/or extended family, places of worship, and other social networks can support a refugee during his or her resettlement process.

\section{Educational Implications}

Given our global society, schools of social work should embed a broader understanding of the experiences of immigrants, asylum-seekers, and refugees into mandated course work. Social workers are practicing in diverse settings (e.g., hospitals, schools, child welfare) where they are called to serve refugee populations. At present, U.S. social work programs are struggling to include this vital material as well as content on human rights (Healy \& Wairire, 2014). Schools of social work could play a significant role in training interdisciplinary healthcare teams and organizing and developing curricula framed by a structural competency approach. Critical components could include content on the migration experience, health outcomes, trauma, trauma-informed systems of care, evidence-based intervention strategies, and policy objectives. In fact, the International Federation of Social Workers (IFSW; 2012) has recommended that refugee studies, crosscultural practice, and access to specialized training in working with refugees and victims of torture and other traumas be implemented within current social work curricula. Such curriculum could be helpful to social work students and practitioners, including healthcare professionals, when conducting trauma assessments and treatment planning with refugees (Agbenyiga \& Huang, 2012).

\section{Policy Implications}

Social workers have historically worked in the trenches with our nation's most vulnerable populations and engaged in advancing human rights, social action, and social and economic justice. These concepts are embedded in the profession's Code of Ethics (NASW, 2009) and educational requirements for social work program accreditation (CSWE, 2015). Refugees do not have the right to fully engage in the political system when they first arrive in the United States, which leaves them voiceless. To fill this void, private and non-profit partners can join with social workers as advocates and political partners to improve services and change laws and federal government policies affecting refugee populations. These coalitions could include churches, Buddhist temples, Mosques, and other faith-based organizations which traditionally have served as safe havens for many refugees and as a critical community support. As noted earlier, a fraction of states requires mandatory mental and physical health screenings of refugees and an even smaller proportion include screening questions relating to traumatic experiences. Social work organizations should work with state and federal elected officials to implement mandatory screenings for all refugees at the time of arrival to assist with their successful resettlement. For example, Willard, Rabin, and Lawless (2014) successfully used a short trauma and 
torture screening tool with resettled Iraqi refugees in Utah. When thorough screenings are not conducted, refugees may not receive the services they require to promote their right to health and successfully integrate into their new home. Of note, in 2016 President Obama announced an increase in refugee admissions from 70,000 to 85,000 for Fiscal Year 2016 and to 100,000 for Fiscal Year 2017. However, at the time of this writing, President Trump lowered the cap, by more than half, to 50,000 refugees, through the signing of executive orders which went into effect on June 29, 2017. The U.S. Congress has not allocated the appropriate funding for services to meet the growing needs of refugees. These funds are necessary to help refugees rebuild their lives and to become productive citizens in their new homes.

\section{Conclusion}

The NASW Code of Ethics (2009) mandates social workers to obtain education and information about issues pertaining to ethnic and cultural diversity, to not support or facilitate means of discrimination, and to work to prevent and eliminate such discrimination through social and political action. A policy statement on immigrants and refugees from NASW (2015) promotes social work education, practice and advocacy around global migration and refugee resettlement and supports policy changes that would better support various refugee groups, including families and children. Likewise, IFSW (2012) supports practice models that involve robust participation of refugees during each stage of intervention and prevention, and advocates for social workers to be engaged in advocacy of refugee needs and rights in order to educate the general public, influence policies in government, as well as in different agencies. Structural competence can support existing social work theories, such as ecological theory, in identifying skill sets that go beyond traditional cultural humility in working with trauma-exposed refugees. This article explored the experiences of Cambodian refugees in order to highlight the various structural forces impacting one trauma-exposed refugee population. As the number of refugees resettling in the United States continues to rise, much can be learned from the long-term resettlement outcomes of Cambodian refugees in the United States so that other more newly arriving refugee populations may be spared from experiencing some of the same preventable health and social problems.

\section{References}

Agbényiga, D., \& Huang, L. (2012). Gendered immigration: Implications and impact on social work education. Advances in Social Work, 13(2), 291-305.

Agrawal, P., \& Venkatesh, A. (2016). Refugee resettlement patterns and state-level health care insurance access in the United States. American Journal of Public Health, 106(4), 662-663. doi: https://doi.org/10.2105/AJPH.2015.303017

Berthold, M. (2000). The effects of exposure to community violence on Khmer refugee adolescents. Journal of Traumatic Stress Studies, 12(3), 455-471. doi: https://doi.org/10.1023/A:1024715003442

Berthold, M. (2015). Human rights-based approaches to clinical social work practice. New York: Springer. 
Berthold, M., Kong, S., Mollica, R. F., Kuoch, T., Scully, M., \& Franke, T. (2014).

Comorbid mental and physical health and health access in Cambodian refugees in the US. Journal of Community Health, 39(6), 1045-1052. doi: https://doi.org/10.1007/s10900-014-9861-7

Bronfenbrenner, U. (1979). The ecology of human development: Experiments by nature and design. Cambridge, MA: Harvard University Press.

Catolico, O. (2013). Seeking life balance: The perceptions of health of Cambodian women in resettlement. Journal of Transcultural Nursing, 24(3), 236-245. doi: https://doi.org/10.1177/1043659613481624

Council on Social Work Education [CSWE]. (2015). Educational Policy and Accreditation Standards for baccalaureate and master's social work programs. Retrieved from http://www.cswe.org/File.aspx?id=81660

Dawson-Hahn, E., Pak-Gorstein, S., Hoopes, H., \& Matheson, J. (2016). Comparison of the nutritional status of overseas refugee children with low-income children in Washington state. PLoS ONE, 11(1), 1-13. doi: https://doi.org/10.1371/journal.pone.0147854

Dharod, J., Xin, H., Morrison, S., Young, A., \& Nsonwu, M. (2013). Lifestyle and foodrelated challenges refugee groups face upon resettlement: Do we have to move beyond job and language training program? Journal of Hunger \& Environmental Nutrition, 8(2), 187-199. doi: https://doi.org/10.1080/19320248.2012.761574

George, M. (2012). Migration traumatic experience and refugee distress: Implications for social work practice. Clinical Social Work Journal, 40, 429-437. doi: https://doi.org/10.1007/s10615-012-0397-y

Grigg-Saito, D., Och, S., Liang, S., Toof, R., \& Silka, L. (2008). Building on the strengths of a Cambodian refugee community through community-based outreach. Health Promotion Practice, 9(4), 415-425. doi: https://doi.org/10.1177/1524839906292176

Grigg-Saito, D., Toof, R., Silka, L., Liang, S., Sou, L., Najarian, L., Och, S. (2010). Long-term development of a "whole community" best practice model to address health disparities in the Cambodian refugee and immigrant community of Lowell, Massachusetts. American Journal of Public Health, 100(11), 2026-2029. doi: https://doi.org/10.2105/AJPH.2009.177030

Healy, L., \& Wairire, G. (2014). Educating for the Global Agenda: Internationally relevant conceptual frameworks and knowledge for social work education. International Social Work, 57(3), 235-247. doi: https://doi.org/10.1177/0020872813519463

Hepworth, D., Rooney, R., Rooney, G., Strom-Gottfried, K., \& Larsen, J. (2010). Direct social work practice: Theory and skills (8th ed.). Belmont, CA: Brooks/Cole.

Higson-Smith, C. (2015). Updating the estimate of refugees resettled in the United States who have suffered torture. St. Paul, MN: Center for Victims of Torture. 
Hooberman, J., Rosenfeld, B., Lhewa, D., Rasmussen, A., \& Keller, A. (2007).

Classifying the torture experiences of refugees living in the United States. Journal of Interpersonal Violence, 22(1), 108-123. doi:

https://doi.org/10.1177/0886260506294999

International Federation of Social Workers [IFSW]. (2012). Refugees. Retrieved from http://ifsw.org/policies/refugees/

Janmyr, M. (2014). Attributing wrongful conduct of implementing partners to UNHCR. Journal of International Humanitarian Legal Studies, 5, 42-69. doi: https://doi.org/10.1163/18781527-00501013

Kiernan, B. (2008). The Pol Pot regime: Race, power, and genocide in Cambodia under the Khmer Rouge, 1975-79 (3rd ed.). New Haven, CT: Yale University Press.

$\mathrm{Ku}, \mathrm{L} .$, \& Matani, S. (2001). Left out: Immigrants' access to health care and insurance. Health Affairs, 20(1), 1247-1256. doi: https://doi.org/10.1377/hlthaff.20.1.247

Kula, S., \& Paik, S. (2016). A historical analysis of Southeast Asian refugee communities: Post-war acculturation and education in the U.S. Journal of Southeast Asian American Education and Advancement, 11(1), 1-23. doi: https://doi.org/10.7771/2153-8999.1127

Lewis, D. (2010). Cambodian refugee families in the United States: "Bending the tree" to fit the environment. Journal of Intergenerational Relationships, 8(1), 5-20. doi: https://doi.org/10.1080/15350770903520635

Lu, J. (2016). Validating visibility and voice: A community-based participatory research study to address the health access of Cambodian Americans (Doctoral dissertation). Retrieved from Digital Commons@UConn.

Marshall, G. N., Schell, T. L., Elliott, M. N., Berthold, S. M., \& Chun, C. (2005). Mental health of Cambodian refugees two decades after resettlement in the United States. JAMA, 294(5), 571-579. doi: https://doi.org/10.1001/jama.294.5.571

Marshall, G. N., Schell, T. L., Wong, E. C., Berthold, S. M., Hambarsoomian, K., Elliott, M.N., \& Gregg, E. W. (2016). Diabetes and cardiovascular disease risk in Cambodian refugees. Journal of Immigrant and Minority Health, 18(1), 110-117. doi: https://doi.org/10.1007/s10903-014-0142-4

Metzl, J., \& Hansen, H. (2014.) Structural competency: Theorizing a new medical engagement with stigma and inequality. Social Science \& Medicine, 103, 126-133. doi: https://doi.org/10.1016/j.socscimed.2013.06.032

Mollica, R., Brooks, R., Tor, S., Lopes-Cardozo, B., \& Silove, D. (2014). The enduring mental health impact of mass violence: A community comparison study of Cambodian civilians living in Cambodia and Thailand. International Journal of Social Psychiatry, 60(1), 6-20. doi: https://doi.org/10.1177/0020764012471597

Mollica, R., Cui, X., McInnes, K., \& Massagli, M. (2002). Science-based policy for psychosocial interventions in refugee camps: A Cambodian example. The Journal of 
Nervous and Mental Disease, 190(3), 158-166. doi: https://doi.org/10.1097/00005053-200203000-00004

Mollica, R., Donelan, K., Tor, S., Lavelle, J., Elias, C., Frankel, M., \& Blendon, R. (1993). The effect of trauma and confinement on functional health and mental health status of Cambodians living in Thailand-Cambodia border camps. Journal of the American Medical Association, 270(5), 581-586. doi: https://doi.org/10.1001/jama.1993.03510050047025

Morantz, G., Rousseau, C., Banerji, A., Martin, C., \& Heymann, J. (2013). Resettlement challenges faced by refugee claimant families in Montreal: Lack of access to child care. Child \& Family Social Work, 18, 318-328. doi: https://doi.org/10.1111/j.13652206.2012.00848.x

National Association of Social Workers [NASW]. (2009). Code of ethics. Retrieved from http://www.socialworkers.org/pubs/code/code.asp

NASW. (2015). Immigration and refugees. In D. Wheeler \& A. McClain (Eds.), Social work speaks: National Association of Social Workers policy statements, 2015-2017 (pp. 176-181). Washington, DC: NASW Press.

NASW. (2016). NASW Standards for Social Work Practice in Health Care Settings. Retrieved from https://www.socialworkers.org/practice/standards/naswhealthcarestandards.pdf

National Cambodian American Health Initiative [NCAHI]. (2007). Health emergency [Report]. West Hartford, CT: Author.

National Consortium of Torture Treatment Programs [NCTTP]. (2015). Descriptive, inferential, functional outcome data on 9,025 torture survivors over six years in the United States. Torture, 25, 34-60.

Office of Refugee Resettlement [ORR]. (2016). Refugees. Retrieved from http://www.acf.hhs.gov/orr/refugees

Peterman, J. N., Wilde, P., Silka, L., Bermudez, O., \& Rogers, B. (2013). Food insecurity among Cambodian refugee women two decades post resettlement. Journal of Immigrant and Minority Health, 15(2), 372-380. doi: https://doi.org/10.1007/s10903$\underline{012-9704-5}$

Porter, M., \& Haslam, N. (2005). Pre-displacement and post-displacement factors associated with mental health of refugees and internally displaced persons. JAMA, 294(5), 602-612. doi: https://doi.org/10.1001/jama.294.5.602

Rotabi, K. (2007). Ecological theory origin from natural to social science or vice versa? A brief conceptual history for social work. Advances in Social Work, 8(1), 113-129.

Shannon, P., Im, H., Becher, E., Simmelink, J., Wieling, E., \& O’Fallon, A. (2012). Screening for war trauma, torture, and mental health symptoms among newly arrived refugees: A national survey of U.S. refugee health coordinators. Journal of 
Immigrant \& Refugee Studies, 10, 380-394. doi:

https://doi.org/10.1080/15562948.2012.674324

Steel, Z., Chey, T., Silove, D., Marnane, C., Bryant, R., \& van Ommeren, M. (2009). Association of torture and other potentially traumatic events with mental health outcomes among populations exposed to mass conflict and displacement: A systematic review and meta-analysis. JAMA, 302(5), 537-549. doi: https://doi.org/10.1001/jama.2009.1132

Substance Abuse and Mental Health Services Administration [SAMHSA]. (2014). Trauma-informed care in behavioral health services: A treatment protocol (TIP), Series 57. HHS Publication No. (SMA) 14-4816. Rockville, MD: SAMHSA

Tasker, R. (1993). Empty dreams: Thais about to close last Cambodian refugee camp. Far Eastern Economic Review, 156(13), 22.

Torture Victims Relief Act (TVRA) of 1998, 22 U.S.C. $\S \S 1-7$ (2016).

United Nations Committee on Economic, Social and Cultural Rights [UNCESCR]. (2000, August). General comment number 14: The right to the highest attainable standard of health (Art. 12 of the Covenant). Retrieved from http://www.refworld.org/docid/4538838d0.html

United Nations General Assembly. (1951, July). Convention relating to the status of refugees. Retrieved from http://www.refworld.org/docid/3be01b964.html

United Nations High Commissioner for Refugees [UNHCR]. (2016). Figures at a glance. Retrieved from http://www.unhcr.org/en-us/figures-at-a-glance.html

United States Census Bureau (USCB). (201. Selected population profile in the United States (SQ201): Cambodian alone or in any combination (405-409) or 300, A01-Z99) or (400-999) (2014). Retrieved from http://factfinder.census.gov/faces/tableservices/jsf/pages/productview.xhtml?pid=AC S_14_1YR_S0201\&prodType=table

Wagner, J., Berthold, S. M., Buckley, T. E., Kuoch, T., \& Scully, M. (2015). Diabetes among refugee populations: What newly arriving refugees can learn from resettled Cambodian Americans. Current Diabetes Reports, 15(8), 56. Advance online publication. doi: https://doi.org/10.1007/s11892-015-0618-1

Willard, C., Rabin, M., \& Lawless, M. (2014). The prevalence of torture and associated symptoms in United States Iraqi refugees. Journal of Immigrant and Minority Health, 16(6), 1069-1076. doi: https://doi.org/10.1007/s10903-013-9817-5

Wong, E., Marshall, G., Schell, T., Elliott, M., Babey, S., \& Hambarsoomian, K. (2011). The unusually poor physical health status of Cambodian refugees two decades after resettlement. Journal of Immigrant and Minority Health, 13(5), 876-882. doi: https://doi.org/10.1007/s10903-010-9392-y

Yoshida, H., Henkin, N., \& Lehrman, P. (2013). Strengthening intergenerational bonds in immigrant and refugee communities. Philadelphia, PA: The Intergenerational 
Center at Temple University. Retrieved from

http://education.temple.edu/sites/education/files/uploads/misc/metlife1112_web.pdf

Author note: Address correspondence to: Jason Ostrander, PhD, MSW, Sacred Heart University, Department of Social Work, 5151 Park Ave, Fairfield, CT 06825, ostranderj@sacredheart.edu 